\title{
The determination of the minimal nitrogen excretion in steers and dairy cows and its physiological and practical implications
}

\author{
BY E. R. ØRSKOV AND N. A. MACLEOD \\ Rowett Research Institute, Bucksburn, Aberdeen AB2 9SB
}

(Received 21 April 1981 - Accepted 14 January 1982)

1. Cattle were maintained by intragastric infusion to see how much nitrogen was excreted on protein-free diets.

2. Minimal N excretion was estimated with two dairy cows in three periods, i.e. when they were non-pregnant and non-lactating, when they were between 117 and $133 \mathrm{~d}$ pregnant and when they were between 220 and $233 \mathrm{~d}$ pregnant. The minimal $\mathrm{N}$ excretion was also estimated on two occasions with two steers when their average live weights were 200 and $350 \mathrm{~kg}$.

3. Average urinary $\mathrm{N}$ excretion without protein infusion was 298,305 and $283 \mathrm{mg} / \mathrm{kg}$ metabolic live weight ( $W^{0.75}$ ) for the non-pregnant cows and for cows during the first and second periods of pregnancy respectively; total $\mathrm{N}$ excretion including the faecal $\mathrm{N}$ was 340,329 and $319 \mathrm{~g} / \mathrm{kg} \mathrm{W}^{0.75}$.

4. For steers the urinary $N$ values were 403 and $295 \mathrm{mg} / \mathrm{kg} \mathrm{W}^{0} \cdot 75$ at 200 and $350 \mathrm{~kg}$ live weight respectively and total $\mathrm{N}$ excretion including faecal $\mathrm{N}$ was 408 and $320 \mathrm{mg} / \mathrm{kg} \mathrm{W0.75}$.

5. Urinary excretion of creatinine was the same for animals given casein via the abomasum as a source of protein or given no protein with mean values for the cows of 13.6 and $14.9 \mathrm{~g} / \mathrm{d}$ for the first and second stages of pregnancy respectively. Mean values for the steers were 6.5 and $7.6 \mathrm{~g}$ creatinine/d at 200 and $350 \mathrm{~kg}$ live weight respectively.

6. It is suggested that the so-called metabolic faecal $\mathrm{N}$ in ruminants, estimated with $\mathrm{N}$-free diets, is mainly endogenous $\mathrm{N}$ derived from tissue breakdown of protein but incorporated in microbial debris and excreted in the faeces.

The problem of assessing the minimal protein requirement for tissue maintenance has been the subject of many experiments and lively debates in the past. One of the first comprehensive experiments with simple-stomached animals was carried out by Terroine \& Sorg-Matter (1927). They reported that the basal urinary $\mathrm{N}$ excreted by simple-stomached animals on $\mathrm{N}$-free diets was $2 \mathrm{mg} \mathrm{N} / \mathrm{kcal}$ or about $0.5 \mathrm{mg} / \mathrm{kJ}$ basal heat production and the total excretion including faecal $\mathrm{N}$ was $0.6-0.8 \mathrm{mg} \mathrm{N} / \mathrm{kJ}$ basal metabolism. Smuts (1935) also reported a linear relation between basal heat production and endogenous urinary $N$ (EUN) loss with $\mathrm{N}$-free diets.

When the EUN was estimated in functioning ruminants it was always found to be considerably lower than in non-ruminants (Mitchell, 1926). In functioning ruminants, however, the so-called metabolic faecal N (MFN) was more than twice as great (Blaxter, 1964) when expressed in relation to dry matter (DM) intake. It is interesting that Blaxter \& Mitchell $(1947,1948)$ argued that although MFN was related to the diet it was still a part of the animal requirement. The question was not resolved since ruminants could not be fed for long periods on $\mathrm{N}$-free diets. The correct place for MFN has still not been resolved since new systems of protein evaluation summarised by Verite et al. (1979) use different methods. Some systems include MFN in the feed value others as a requirement by the animal. Blaxter (1964) suggested that $\mathrm{N}$ was trapped by micro-organisms in the gut which were later excreted in the faeces and that this might be the cause of the high MFN in ruminants. Mason (1969) showed by chemical methods that the MFN largely consisted of microbial debris, and Ørskov et al. (1970) showed that the MFN could be increased, and urinary $\mathrm{N}$ decreased, when caecal fermentation was increased. The Agricultural Research Council (1980) in their review of literature on ruminant protein metabolism concluded that the MFN is largely an inevitable consequence of microbial fermentation of carbohydrate in the rumen giving rise to some indigestible microbial cell walls. The digestibility of 
microbial protein was used as a factor in the system proposed by the Agricultural Research Council for estimating protein and thus the MFN in effect was considered as part of the losses in utilization of microbial $\mathbf{N}$. The tissue $\mathrm{N}$ requirement was simply assessed as the daily excretion EUN.

The technique of maintaining ruminants for long periods by the intrarumen infusion of nutrients enabled further investigation of $\mathrm{N}$ metabolism in ruminants to be made because it was possible to sustain animals using $\mathrm{N}$-free infusates. When young lambs were maintained by this technique (Ørskov \& Grubb, 1978; Storm \& Ørskov, 1979) the EUN was two to three times greater than that reported in the literature as summarized by the Agricultural Research Council (1980). In the present study the excretion of $\mathbf{N}$ was measured in steers of different weights and by dairy cows at different stages of pregnancy both of which were maintained by $\mathrm{N}$-free infusates. The excretion of urea- $\mathrm{N}$ and creatinine were also measured at different rates of casein infusion.

\section{MATERIALS AND METHODS}

Animals. In Expt 1 two Friesian cows were used when they were dry and not pregnant (stage A), when they were between 117 and $133 \mathrm{~d}$ pregnant (stage B) and when they were between 220 and $233 \mathrm{~d}$ pregnant (stage C). Mean live weight was 505,654 and $693 \mathrm{~kg}$ in each of these periods respectively.

In Expt 2 two Friesian steers were used, when they weighed on average $200 \mathrm{~kg}$ (stage A) and again when they weighed on average $342 \mathrm{~kg}$ live weight (stage B).

Surgery. Cows and steers were fitted with rumen cannulas which had an internal diameter of $45 \mathrm{~mm}$. Cows were fitted with abomasal catheters consisting of a transparent vinyl tube of $12.7 \mathrm{~mm}$ internal diameter and $19.1 \mathrm{~mm}$ external diameter (Portex Ltd., Hythe, Kent); for steers the corresponding measurements were 9.5 and $13.8 \mathrm{~mm}$.

Infusion procedure and solutions. The infusion procedure used for the cows and the steers was only slightly modified from that described for lambs (Ørskov, Grubb, Wenham et al. 1979). The animal was allowed access to the basal feed, usually dried grass, when the infusion commenced. Food was withdrawn when the desired level of infusion had been reached. The usual procedure was to increase the amount of infusate in increments equivalent to 0.25 times the estimated maintenance requirement for energy and maintain the new level for at least $2 \mathrm{~d}$. This meant that the desired infusion level was usually reached in 10-14 d. Energy for maintenance was estimated to be $450 \mathrm{~kJ}$ metabolic live weight ( $\left.\mathrm{W}^{0.75}\right)$ and was supplied as volatile fatty acids (VFA) and casein. Casein- $\mathbf{N}$ for maintenance was estimated as $0.7 \mathrm{~g} / \mathrm{kg} \mathrm{W}^{0.75}$. When the observations had been completed in each stage, approximately 21 rumen contents from a normal animal were passed into the rumen and the animals allowed access to food. Normal levels of food intake were generally reached in 5-7 d.

The mixture of VFA used for all trials consisted of $(\mathrm{mmol} / \mathrm{mol}) 65$ acetic, 25 propionic and 10 butyric acids. The buffer solutions were similar to those described by Ørskov, Grubb, Wenham et al. (1979) as were the solutions of minerals, trace elements and vitamins which were given in proportion to $\mathbf{W}^{\mathbf{0} 75}$. Major minerals were mixed with the VFA and infused into the rumen. The vitamins and linoleic acid were included in the casein solution, and the trace minerals were injected into the abomasal catheter once daily. Rumen $\mathrm{pH}$ was measured at least twice daily and if $\mathrm{pH}$ was 5.8 or less it was adjusted by injection of more buffer solution or by temporarily reducing the VFA infusion.

Treatments. For each stage, with both cows and steers, the protein infused was reduced from maintenance or $1.5 \times$ maintenance to zero in steps of multiples of maintenance. When the protein was reduced the VFA infusion was increased to adjust for the change in energy level. The days on each level are given in Tables 1-3 for stages A, B and C for cows (Expt 1) and in Tables 4 and 5 for stages A and B for steers (Expt 2). The last period in each 


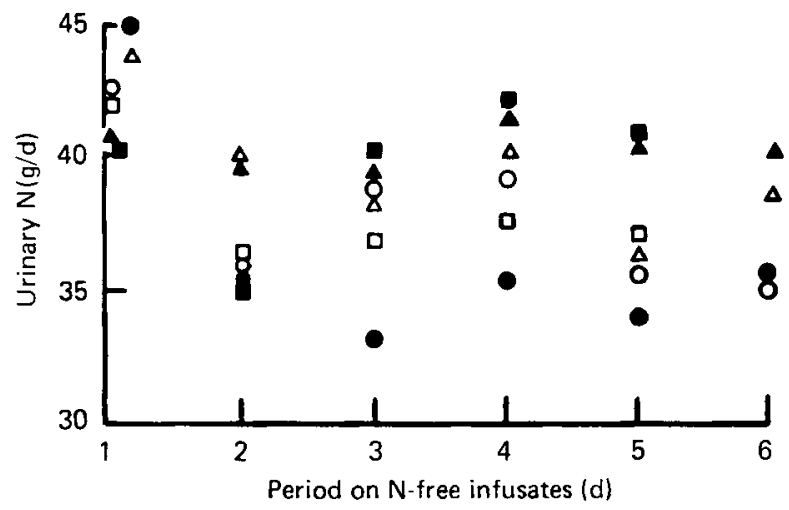

Fig. 1. Expt. 1. The effect of day of infusion of nitrogen-free diets on urinary $\mathrm{N}$ in stage $\mathrm{A}(\mathrm{O}), \mathrm{B}$ $(\triangle \Delta)$ and $C(\square \square)$ for cows nos. $351(\bigcirc \Delta \square)$ and $355(O \triangle \square)$.

stage of investigation in which the $\mathrm{N}$-free infusate was given usually consisted of $6 \mathrm{~d}$ except for stage $\mathrm{C}$ for cows, when it was $5 \mathrm{~d}$ only. As referred to later the results do not include the first day of $\mathrm{N}$-free infusion.

Collection procedure. Faeces were collected and bulked for each period for the cows while for the steers they were bulked for the whole collection period. This was because on several days no faeces were excreted. Urine was collected daily and preserved with sulphuric acid at $\mathrm{pH}$ below 5 .

Analytical procedure. $\mathrm{N}$ was estimated in urine and faeces according to the procedure described by Davidson et al. (1970). Urea was estimated using the technique described by Technicon Instruments Co. Ltd., based on a modification of a technique by Marsh et al. (1965). Creatinine was estimated by the technique described in Technicon Instruments Co. Ltd., based on the method described by Hawk et al. (1947).

\section{RESULTS}

The results of the five experimental stages are given in Tables 1-5. Values for the first day of the period when no protein was infused were excluded from the mean values. The reason for this can be seen in Fig. 1 where the $\mathrm{N}$ output on the period without protein infusion is plotted $v$. period of infusion. Excretion on the first day was different but there was no apparent systematic change during the following days.

\section{Expt 1}

Stage $A$. The results are given in Table 1. While cow no. 351 was in positive $\mathbf{N}$ balance during the period when sufficient protein was infused for maintenance, cow no. 355 was not. Cow no. 351 excreted $317 \mathrm{mg} \mathrm{N} / \mathrm{kg} \mathrm{W}^{0 \cdot 75}$ and cow no. 355 excreted $280 \mathrm{mg} \mathrm{N} / \mathrm{kg} \mathrm{W}^{0.75}$ in the urine, and total excretions, including the faecal $\mathrm{N}$, were 352 and $328 \mathrm{mg} \mathrm{N} / \mathrm{kg} \mathrm{W}^{0.75}$ in the period when no protein was infused respectively. The amount of faecal $\mathrm{N}$ apparently did not depend on whether or not protein was infused. Creatinine and urea were not estimated during this stage.

Stage $B$. The rates of infusion and excretion of $\mathbf{N}$ are given in Table 2. Faecal $\mathbf{N}$ was not consistently influenced by level of protein infusion and was less than $10 \%$ of the total $\mathrm{N}$ excretion. The $\mathrm{N}$ excretion in the urine without $\mathrm{N}$ infusion was 283 and $327 \mathrm{mg} / \mathrm{kg} \mathrm{W}^{0.75}$ for cows nos. 351 and 355 respectively, and total $N$ excretions were 298 and $359 \mathrm{mg} \mathrm{N} / \mathrm{kg} \mathrm{W}^{0 \cdot 75}$. The excretion of creatinine was unaffected or only very slightly affected by the level of protein infusion, but the proportion of urea- $\mathrm{N}$ increased with increasing urinary $\mathbf{N}$. 
Table 1. Expt 1, stage A. Effect of protein infusion on nitrogen excretion in non-lactating, non-pregnant Friesian cows

(No. of $d$ of infusion given in parentheses)

\begin{tabular}{|c|c|c|c|c|c|c|}
\hline Period & $\begin{array}{l}\text { Energy lev } \\
\text { (multiples }\end{array}$ & $\begin{array}{l}\text { Protein level } \\
\text { maintenance) }\end{array}$ & $\underset{\text { infused }}{\mathrm{N}} \underset{\mathrm{g} / \mathrm{d})}{\mathrm{N}}$ & $\begin{array}{c}\text { Urinary } \\
N \\
(\mathrm{~g} / \mathrm{d})\end{array}$ & $\begin{array}{c}\text { Faecal } \\
N \\
(\mathrm{~g} / \mathrm{d})\end{array}$ & $\underset{\substack{\text { balance } \\
(\mathrm{g} / \mathrm{d})}}{\mathrm{N}}$ \\
\hline & \multicolumn{2}{|c|}{ Cow no. 351} & & & & \\
\hline $1(5)$ & $1 \cdot 0$ & 1.0 & 83.7 & $60 \cdot 8$ & 4.5 & 18.4 \\
\hline $2(4)$ & 1.0 & 0.5 & 41.4 & 56.8 & 2.5 & -17.9 \\
\hline \multirow[t]{2}{*}{$3(5)^{*}$} & 1.0 & 0 & 0 & 29.5 & 5.4 & -34.9 \\
\hline & \multicolumn{2}{|c|}{ Cow no. 355} & & & & \\
\hline $1(5)$ & 1.0 & 1.0 & $79 \cdot 4$ & 91.5 & 3.9 & $-16 \cdot 0$ \\
\hline $2(4)$ & $1 \cdot 0$ & 0.5 & $42 \cdot 2$ & $64 \cdot 3$ & $3 \cdot 0$ & $-25 \cdot 1$ \\
\hline $3(5)$ & 1.0 & 0 & 0 & 33.9 & 3.8 & $-37 \cdot 7$ \\
\hline
\end{tabular}

* First day of zero $\mathrm{N}$ infusion not included.

Table 2. Expt 1, stage B. Effect of protein infusion on nitrogen excretion in pregnant Friesian cows during days 117-130 of gestation

(No. of $d$ of infusion given in parentheses)

\begin{tabular}{|c|c|c|c|c|c|c|c|c|}
\hline Period & $\begin{array}{c}\text { Energy } \\
\text { level } \\
\text { (mu } \\
\text { main }\end{array}$ & $\begin{array}{l}\text { Protein } \\
\text { level } \\
\text { es of } \\
\text { ance) }\end{array}$ & $\begin{array}{c}N \\
\text { infused } \\
(\mathrm{g} / \mathrm{d})\end{array}$ & $\underset{(\mathrm{g} / \mathrm{d})}{\text { Urinary }}$ & $\begin{array}{l}\text { Faecal } \\
N \\
(\mathrm{~g} / \mathrm{d})\end{array}$ & $\begin{array}{c}\mathrm{N} \\
\text { balance } \\
(\mathrm{g} / \mathrm{d})\end{array}$ & $\begin{array}{c}\text { Urea-N } \\
(\mathrm{g} / \mathrm{kg} \mathrm{N})\end{array}$ & $\begin{array}{l}\text { Creatinine } \\
(\mathrm{g} / \mathrm{d})\end{array}$ \\
\hline & \multicolumn{2}{|c|}{ Cow no. 351} & & & & & & \\
\hline $1(2)$ & 1.0 & 1.5 & $115 \cdot 5$ & $112 \cdot 0$ & 1.8 & $1 \cdot 7$ & 912 & $15 \cdot 4$ \\
\hline $2(2)$ & 1.0 & 1.0 & 83.0 & 90.6 & 1.8 & $-9 \cdot 4$ & 830 & $14 \cdot 1$ \\
\hline $3(2)$ & 1.0 & 0.5 & $41 \cdot 8$ & 67.0 & $2 \cdot 2$ & $-27 \cdot 4$ & 625 & 16.5 \\
\hline \multirow[t]{2}{*}{$4(5)^{*}$} & 1.0 & 0 & 0 & $37 \cdot 7$ & $2 \cdot 0$ & $-39 \cdot 7$ & 473 & $14 \cdot 1$ \\
\hline & \multicolumn{2}{|c|}{ Cow no. 355} & & & & & & \\
\hline $1(2)$ & 1.0 & 1.5 & $109 \cdot 8$ & $106 \cdot 2$ & $4 \cdot 1$ & -0.5 & 844 & 12.7 \\
\hline $2(2)$ & 1.0 & 1.0 & $78 \cdot 8$ & $85 \cdot 7$ & 3.0 & -9.9 & 928 & 10.9 \\
\hline $3(2)$ & 1.0 & 0.5 & $44 \cdot 0$ & $51 \cdot 2$ & 5.5 & $-12 \cdot 7$ & 574 & $12 \cdot 9$ \\
\hline $4(5)^{*}$ & 1.0 & 0 & 0 & $41 \cdot 2$ & 4.0 & $-45 \cdot 2$ & 546 & 12.0 \\
\hline
\end{tabular}

* The first day of zero $\mathrm{N}$ infusion was not included.

Stage $C$. Results were calculated as for stages A and B and are summarized in Table 3. The excretion of $\mathrm{N}$ was greater than in stage $\mathrm{A}$, but urinary $\mathrm{N}$ excretions without protein infusion were 248 and $318 \mathrm{mg} / \mathrm{kg} \mathrm{W}^{0.75}$ for cows nos. 351 and 355 respectively, and total body $\mathrm{N}$ excretion was 287 and $350 \mathrm{mg} / \mathrm{kg} \mathrm{W}^{0.75}$. Faecal $\mathrm{N}$ and creatinine excretion were not consistently affected by the level of protein infusion and the proportion of urea-N increased with increasing $\mathbf{N}$ excretion.

\section{Expt 2}

Stage $A$. In this stage (see Table 4 ) the energy level was kept at $1 \cdot 5$ times maintenance until the last $5 \mathrm{~d}$. Reducing the energy level did not appear to affect the excretion of $\mathrm{N}$ in the 
Table 3. Expt 1, stage C. Effect of protein infusion on nitrogen excretion in pregnant Friesian cows during days 220-233 of gestation

(No. of $d$ of infusion given in parentheses)

\begin{tabular}{|c|c|c|c|c|c|c|c|c|}
\hline Period & $\begin{array}{c}\text { Energy } \\
\text { level } \\
\text { (mul } \\
\text { of ma }\end{array}$ & $\begin{array}{l}\text { Protein } \\
\text { level } \\
\text { es of } \\
\text { nance) }\end{array}$ & $\begin{array}{c}N \\
\text { infusion } \\
(\mathrm{g} / \mathrm{d})\end{array}$ & $\begin{array}{c}\text { Urinary } \\
N \\
(\mathrm{~g} / \mathrm{d})\end{array}$ & $\begin{array}{l}\text { Faecal } \\
N \\
(\mathrm{~g} / \mathrm{d})\end{array}$ & $\begin{array}{c}\mathrm{N} \\
\text { balance } \\
(\mathrm{g} / \mathrm{d})\end{array}$ & $\begin{array}{c}\text { Urea-N } \\
(\mathrm{g} / \mathrm{kg} \mathrm{N})\end{array}$ & $\begin{array}{c}\text { Creatinine } \\
(\mathrm{g} / \mathrm{d})\end{array}$ \\
\hline & \multicolumn{2}{|c|}{ Cow no. 351} & & & & & & \\
\hline $1(3)$ & 1.0 & 1.5 & $141 \cdot 4$ & $134 \cdot 4$ & 4.9 & $2 \cdot 1$ & 907 & $15 \cdot 7$ \\
\hline $2(3)$ & 1.0 & 1.0 & $97 \cdot 1$ & 99.0 & 4.7 & -6.6 & 828 & $16 \cdot 1$ \\
\hline $3(3)$ & 1.0 & 0.5 & $50 \cdot 3$ & 62.8 & $4 \cdot 7$ & $-17 \cdot 2$ & 767 & $15 \cdot 4$ \\
\hline \multirow[t]{2}{*}{$4(4)^{*}$} & 1.0 & 0 & 0 & $34 \cdot 2$ & $5 \cdot 4$ & $-39 \cdot 6$ & 521 & 14.7 \\
\hline & \multicolumn{2}{|c|}{ Cow no. 355} & & & & & & \\
\hline $1(3)$ & 1.0 & 1.5 & $135 \cdot 1$ & $136 \cdot 4$ & $6 \cdot 3$ & $-7 \cdot 6$ & 920 & 14.5 \\
\hline $2(3)$ & 1.0 & 1.0 & 91.3 & $95 \cdot 3$ & 3.7 & -7.7 & 865 & 13.6 \\
\hline $3(3)$ & 1.0 & 0.5 & 46.9 & $69 \cdot 2$ & 3.9 & $-26 \cdot 2$ & 717 & 13.7 \\
\hline $4(4)^{*}$ & $1 \cdot 0$ & 0 & 0 & $42 \cdot 0$ & $4 \cdot 3$ & $-46 \cdot 3$ & 620 & $15 \cdot 4$ \\
\hline
\end{tabular}

* First day of zero $\mathrm{N}$ infusion not included.

Table 4. Expt 2, stage A. Effect of level of casein infusion and energy level on total nitrogen, urea and creatinine excretion in two Friesian steers at $203 \mathrm{~kg}$ live weight

(No. of $\mathrm{d}$ of infusion given in parentheses)

\begin{tabular}{|c|c|c|c|c|c|c|c|c|}
\hline Period & $\begin{array}{c}\text { Energy } \\
\text { level } \\
\text { (mult } \\
\text { main }\end{array}$ & $\begin{array}{c}\text { Protein } \\
\text { level } \\
\text { les of } \\
\text { ance) }\end{array}$ & $\begin{array}{c}\mathrm{N} \\
\text { infusion } \\
(\mathrm{g} / \mathrm{d})\end{array}$ & $\begin{array}{c}\text { Urinary } \\
\mathrm{N} \\
(\mathrm{g} / \mathrm{d})\end{array}$ & $\begin{array}{c}\text { Average } \\
\text { faecal } \\
N \\
(\mathrm{~g} / \mathrm{d})\end{array}$ & $\begin{array}{c}\mathrm{N} \\
\text { balance } \\
(\mathrm{g} / \mathrm{d})\end{array}$ & $\begin{array}{c}\text { Urea } N \\
(\mathrm{~g} / 100 \mathrm{~g} \mathrm{~N})\end{array}$ & $\begin{array}{c}\text { Creatinine } \\
\text { (g/d) }\end{array}$ \\
\hline & \multicolumn{2}{|c|}{ Steer 213} & & & & & & \\
\hline $1(3)$ & $1 \cdot 5$ & 1.5 & $57 \cdot 4$ & $45 \cdot 4$ & $0 \cdot 3$ & $11 \cdot 7$ & - & 5.9 \\
\hline $2(3)$ & 1.5 & 1.0 & $37 \cdot 0$ & $35 \cdot 7$ & 0.3 & $-3 \cdot 0$ & $67 \cdot 0$ & $6 \cdot 2$ \\
\hline $3(3)$ & $1 \cdot 5$ & 0.5 & $18 \cdot 6$ & $30 \cdot 4$ & 0.3 & $-12 \cdot 1$ & 61.5 & 6.7 \\
\hline $4(2)^{*}$ & $1 \cdot 5$ & 0 & 0 & $20 \cdot 7$ & 0.3 & $-21 \cdot 0$ & 46.6 & $5 \cdot 4$ \\
\hline \multirow[t]{2}{*}{$5(4)$} & 1.0 & 0 & 0 & $20 \cdot 5$ & 0.3 & $-20 \cdot 8$ & $41 \cdot 1$ & $6 \cdot 7$ \\
\hline & \multicolumn{2}{|c|}{ Steer 215} & & & & & & \\
\hline $1(3)$ & $1 \cdot 5$ & $1 \cdot 5$ & $58 \cdot 7$ & $41 \cdot 8$ & $0 \cdot 2$ & $8 \cdot 7$ & $61 \cdot 6$ & $6 \cdot 6$ \\
\hline $2(3)$ & 1.5 & 1.0 & $39 \cdot 5$ & $34 \cdot 3$ & 0.2 & 5.0 & 61.7 & $6 \cdot 8$ \\
\hline $3(3)$ & $1 \cdot 5$ & 0.5 & $16 \cdot 7$ & $29 \cdot 2$ & 0.2 & $-12 \cdot 7$ & $68 \cdot 2$ & $6 \cdot 8$ \\
\hline $4(2)^{*}$ & 1.5 & 0 & 0 & $17 \cdot 0$ & 0.2 & $-17 \cdot 2$ & - & - \\
\hline $5(4)$ & $1 \cdot 0$ & 0 & 0 & $22 \cdot 9$ & 0.2 & $-23 \cdot 1$ & $54 \cdot 7$ & $7 \cdot 4$ \\
\hline
\end{tabular}

* First day of zero $\mathrm{N}$ infusion was not included.

absence of protein infusion. Urinary $\mathrm{N}$ excretion without protein infusion was 381 and $426 \mathrm{mg} / \mathrm{kg} \mathrm{W}^{0 \cdot 75}$ for steers nos. 213 and 215 respectively, and total excretion was 387 and $428 \mathrm{mg} \mathrm{N} / \mathrm{kg} \mathrm{W}^{0 \cdot 75}$. Separation of faeces and urine was difficult in this trial and so some soft faeces contaminated the urine. The excretion of creatinine was relatively constant regardless of infusion level, while the proportion of urea- $\mathrm{N}$ increased as the total amount of $\mathrm{N}$ excreted increased. 
Table 5. Expt 2, stage B. Effect of protein infusion on excretion of total nitrogen, urea nitrogen and creatinine in Friesian steers 213 and 215 weighing respectively 305 and $380 \mathrm{~kg}$ live weight

(No. of $d$ of infusion given in parentheses)

\begin{tabular}{|c|c|c|c|c|c|c|c|c|}
\hline Period & $\begin{array}{r}\text { Energy } \\
\text { level } \\
\text { (mu } \\
\text { mai }\end{array}$ & $\begin{array}{l}\text { Protein } \\
\text { level } \\
\text { es of } \\
\text { ance) }\end{array}$ & $\begin{array}{c}N \\
\text { infusion } \\
(\mathrm{g} / \mathrm{d})\end{array}$ & $\begin{array}{c}\text { Urinary } \\
N \\
(\mathrm{~g} / \mathrm{d})\end{array}$ & $\begin{array}{c}\text { Average } \\
\text { faecal } \\
N \\
(\mathrm{~g} / \mathrm{d})\end{array}$ & $\underset{\substack{\mathrm{g} \\
\text { balance } \\
\mathrm{g} / \mathrm{d})}}{\mathrm{N}}$ & $\begin{array}{c}\text { Urea-N } \\
(\mathrm{g} / 100 \mathrm{~g} \mathrm{~N})\end{array}$ & $\begin{array}{c}\text { Creatinine } \\
(\mathrm{g} / \mathrm{d})\end{array}$ \\
\hline & \multicolumn{2}{|c|}{ Steer 213} & & & & & & \\
\hline $1(3)^{*}$ & 1.0 & 1.5 & $76 \cdot 4$ & $60 \cdot 4$ & 1.0 & 15.0 & 65.4 & 6.8 \\
\hline $2(3)$ & $1 \cdot 0$ & $1 \cdot 0$ & 52.9 & 51.8 & $1 \cdot 0$ & 0.1 & 50.5 & 6.9 \\
\hline $3(3)$ & 1.0 & 0.5 & 26.9 & $33 \cdot 1$ & 1.0 & -8.0 & $44 \cdot 3$ & 6.9 \\
\hline \multirow[t]{2}{*}{$4(4)^{*}$} & 1.0 & 0 & 0 & 22.1 & 1.0 & $-23 \cdot 1$ & 37.9 & 6.3 \\
\hline & \multicolumn{2}{|c|}{ Steer 215} & & & & & & \\
\hline $1(3)$ & 1.0 & 1.5 & 86.7 & $78 \cdot 3$ & $3 \cdot 2$ & $5 \cdot 2$ & 81.9 & $9 \cdot 3$ \\
\hline $2(3)$ & 1.0 & 1.0 & $60 \cdot 3$ & 58.0 & $3 \cdot 2$ & -1.1 & $73 \cdot 5$ & $8 \cdot 6$ \\
\hline $3(3)$ & 1.0 & 0.5 & $30 \cdot 0$ & 36.7 & $3 \cdot 2$ & -9.9 & $52 \cdot 0$ & 7.8 \\
\hline $4(4)^{*}$ & $1 \cdot 0$ & 0 & 0 & $25 \cdot 4$ & $3 \cdot 2$ & $-28 \cdot 6$ & 34.9 & $8 \cdot 3$ \\
\hline
\end{tabular}

* The value for first day of zero $\mathrm{N}$ infusion was excluded.

Stage $B$. In this stage the energy infused was not in excess of the estimated maintenance requirement. The results are given in Table 5 . The faeces were bulked for the whole period since on several days no faeces were excreted. Urinary $\mathbf{N}$ without $\mathbf{N}$ infusion was $295 \mathrm{mg} / \mathrm{kg} \mathrm{W}^{0.75}$ for both steers, and the total $\mathrm{N}$ excretion was 308 and $332 \mathrm{mg} / \mathrm{kg} \mathrm{W}^{0.75}$ for steers nos. 213 and 215 respectively. Creatinine excretion was not consistently affected by $\mathrm{N}$ infusion, but the proportion of urea- $\mathrm{N}$ increased with the amount of $\mathrm{N}$ excreted.

\section{DISCUSSION \\ Excretion of urea}

The excretion of urea- $\mathrm{N}$ closely reflected amount of $\mathrm{N}$ excretion. It is of interest to compare the values obtained with those quoted in the literature. In Table 6 examples from functioning ruminants and non-functioning ruminants fed on liquids only are given, for $\mathrm{N}$-free, nearly $\mathrm{N}$-free or protein-rich diets. It is seen that the percentage of urea in the urine can vary from $70 \mathrm{mg} / \mathrm{g} \mathrm{N}$ on $\mathrm{N}$-free diets given to functioning ruminants, to approximately $900 \mathrm{mg} / \mathrm{g} \mathrm{N}$ for the animals nourished by infusion, in the present work. Low excretion of urea- $\mathbf{N}$ when $\mathbf{N}$-free diets are given to ruminants is probably related to very efficient recycling into the gut; thus $\mathbf{N}$ excreted in the urine would consist mainly of compounds such as creatinine (which amounted to $320 \mathrm{mg} / \mathrm{g} \mathrm{N}$ in the trial of Kehar et al. (1943)) and allantoin arising from degradation of purine bases resulting from excretion of microbial nucleic acid- $\mathrm{N}$ and small amounts of other more complex products of protein degradation which are excreted in the urine.

The proportion of urea- $\mathrm{N}$ excreted on $\mathrm{N}$-free diets was higher when the nutrients were directly infused, as in the present work, or when they by-passed the rumen, as in milk-fed lambs and calves. The higher proportion is most likely a result of a reduced recycling of $\mathbf{N}$ into the gut since there was no rumen fermentation to sustain, and to the fact that products of microbial nucleic acid degradation would not be present. The highest values recorded for urea excretion were noted when protein was given in excess of requirement. There is little doubt that the values recorded, in which urea and creatinine accounted for 
Minimal $N$ excretion in steers and dairy cows

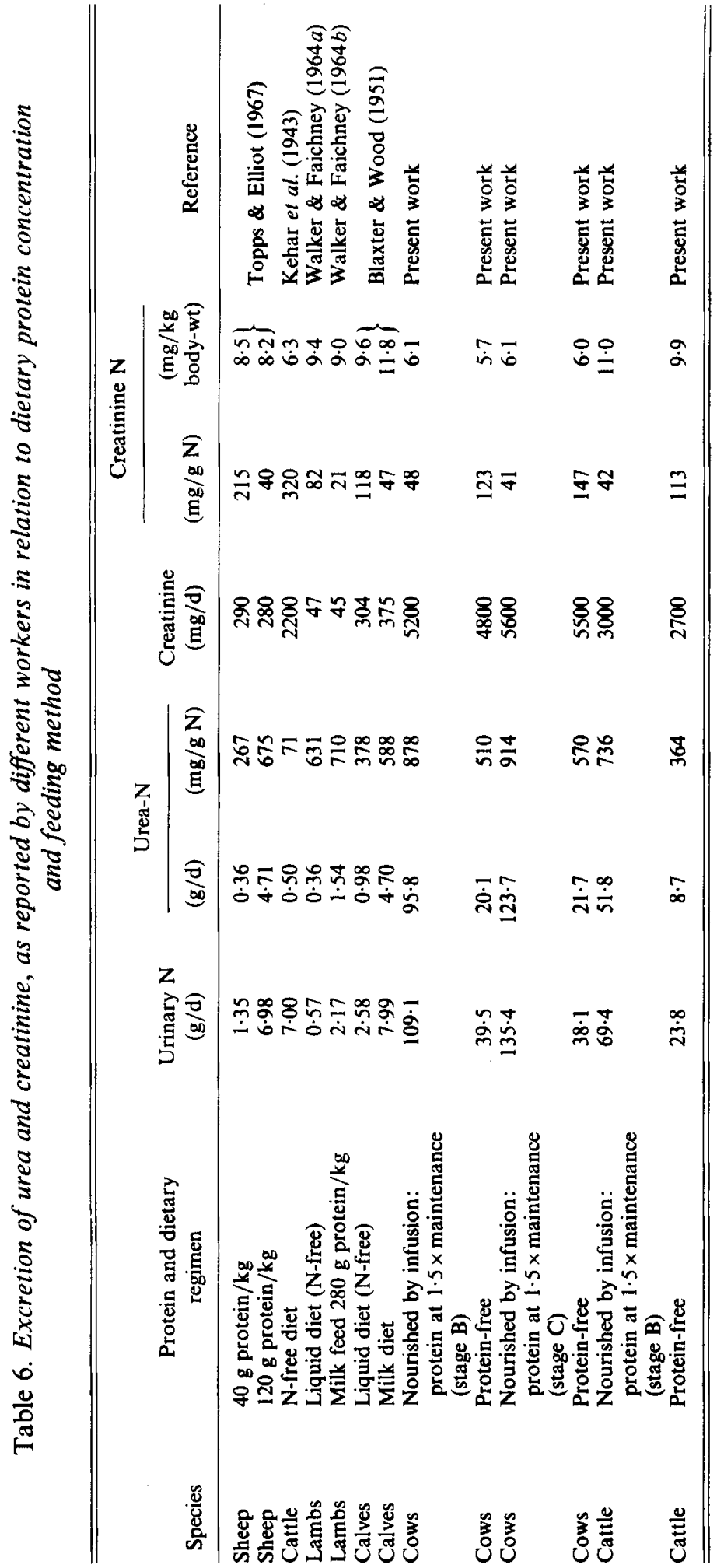


Table 7. The minimal nitrogen excretion of steers and cows

\begin{tabular}{|c|c|c|c|c|c|c|c|}
\hline & & & ary $\mathrm{N}$ & xcretion & & & Agricultural \\
\hline & & & & & Tota & $\mathrm{N}$ excretion & Council \\
\hline & & Mean & SE & $\left(\mathrm{mg} / \mathrm{kgW}^{0.75}\right)$ & $(g / d)$ & $\left(\mathrm{mg} / \mathrm{kgW}^{0.75}\right)$ & $(\mathrm{g} / \mathrm{d})$ \\
\hline Steer no. 213 & & $20 \cdot 5$ & $2 \cdot 3$ & 381 & $20 \cdot 8$ & 387 & 6.9 \\
\hline Steer no. 215$\}$ & $203 \mathrm{~kg}$ live wt & $22 \cdot 9$ & 5.8 & 426 & $23 \cdot 1$ & 429 & $6 \cdot 9$ \\
\hline Steer no. 213 & $305 \mathrm{~kg}$ live wt & $22 \cdot 1$ & 1.8 & 295 & $23 \cdot 1$ & 308 & 7.9 \\
\hline Steer no. 215 & $380 \mathrm{~kg}$ live $\mathrm{wt}$ & $25 \cdot 4$ & $2 \cdot 7$ & 295 & 28.6 & 332 & 8.5 \\
\hline Cow no. 351 & Non-pregnant & 33.9 & 3.8 & 317 & 37.7 & 352 & $9 \cdot 2$ \\
\hline Cow no. 355 & Non-pregnant & $29 \cdot 5$ & $2 \cdot 1$ & 280 & 34.9 & 328 & $9 \cdot 2$ \\
\hline Cow no. 351$\}$ & $130 \mathrm{~d}$ nreona & $37 \cdot 7$ & $3 \cdot 3$ & 283 & 39.7 & 298 & $9 \cdot 7$ \\
\hline Cow no. 355$\}$ & $130 \mathrm{~d}$ pregnant & $41 \cdot 2$ & $1 \cdot 1$ & 327 & $45 \cdot 2$ & 359 & $9 \cdot 7$ \\
\hline Cow no. 351 & & $34 \cdot 2$ & $1 \cdot 1$ & 248 & 39.6 & 287 & $9 \cdot 7$ \\
\hline Cow no. 355$\}$ & $233 \mathrm{~d}$ pregnant & $42 \cdot 0$ & $8 \cdot 0$ & 318 & $46 \cdot 3$ & 350 & $9 \cdot 7$ \\
\hline
\end{tabular}

more than $900 \mathrm{mg} / \mathrm{g}$ urinary $\mathrm{N}$ are only possible because no microbial fermentation took place in the rumen and so the excretion of products from nucleic acid degradation would be absent.

\section{Total $N$ excretion in the absence of protein infusion}

A summary of the results in Tables 1-5 is given in Table 7, where the urinary and total excretions of $\mathrm{N}$ are compared with the values proposed by the Agricultural Research Council (1980) for EUN and taken to represent the requirement for tissue $\mathrm{N}$ maintenance. It can be seen that the values from the current work are greater by two to three times than the mean value for EUN.

The urinary excretions of $\mathrm{N}$ expressed on a $\mathrm{W}^{0.75}$ basis are similar to those obtained with lambs using the same technique (Ørskov \& Grubb, 1978; Storm \& Ørskov, 1979) and it must therefore be asked whether the results could be an artifact of the technique used. The same technique has, however, produced normal utilization of protein both in the trials here and with microbial protein (Storm \& Ørskov, 1979), and the utilization of energy was slightly greater than that expected on normal feeding (Ørskov, Grubb, Smith et al. 1979). It seems that the values obtained are closer to the sum of EUN and the so-called MFN, and that the contention of Blaxter \& Mitchell $(1947,1948)$ that MFN had to be included as an animal requirement was closer to being correct than the use of EUN alone, but no technique was available to ascertain whether it was correct or not.

The differences between results obtained here and those in the literature (Agricultural Research Council, 1980) in estimation of minimum excretion of $\mathrm{N}$ can be reconciled if we postulate that the so-called MFN in ruminants estimated with $\mathrm{N}$-free diets or low-N diets mainly consists of endogenous $\mathrm{N}$ originating from tissue metabolism and that its appearance as faecal $\mathrm{N}$ is a result of recycling of $\mathrm{N}$ from the blood or saliva to the rumen, from which a proportion will be excreted as indigestible microbial debris (Mason, 1969). This would support the evidence that it is possible to manipulate the route of excretion (Ørskov et al. 1970 ) and that an infusion of carbohydrate into the large intestine leads to an increase in faecal $\mathbf{N}$ and a concomitant decrease in urinary $\mathbf{N}$ with lambs nourished by intragastric nutrition (Ørskov \& Grubb, 1978).

In order to test this hypothesis a comparison was made with results from experiments where $\mathrm{N}$-free diets have been given to ruminants, albeit for short periods. Comparisons were also made with values obtained from fasting sheep and from milk or liquid-fed lambs and calves given $\mathrm{N}$-free diets. Values for EUN obtained by extrapolation are not included in 
Table 8. Comparison of nitrogen excretion in liquid-fed calves, fasting sheep, goats and cattle, sheep and cattle on $N$-free infusates and sheep given $N$-free diets on excretion of $N$ via urine and faeces

(Excretion of $\mathrm{N}$ calculated as $\mathrm{mg} / \mathrm{kg} \mathrm{W}^{0 \cdot 75}$ )

\begin{tabular}{|c|c|c|c|c|c|}
\hline $\begin{array}{c}\text { Species and } \\
\text { dietary regimen }\end{array}$ & $\begin{array}{l}\text { Live wt } \\
\text { (kg) }\end{array}$ & $\begin{array}{l}\text { Urinary } \\
\mathrm{N}\end{array}$ & $\begin{array}{c}\text { Faecal } \\
\mathbf{N}\end{array}$ & $\begin{array}{c}\text { Total } \\
\mathbf{N}\end{array}$ & Reference \\
\hline Fasting sheep & 55 & 372 & - & 372 & Blaxter (1962) \\
\hline Fasting sheep & $50^{*}$ & 371 & 33 & $404)$ & \\
\hline Fasting goats & $36^{*}$ & 358 & 29 & $387\}$ & Morris \& Roy (1939) \\
\hline Fasting cows & $525^{*}$ & 272 & 61 & 333 & \\
\hline Lambs $\mathrm{N}$-free infusates & 25 & 427 & $-\dagger$ & 427 & Ørskov \& Grubb (1978) \\
\hline Lambs $N$-free infusates & 30 & 340 & $-\dagger$ & 340 & Storm \& Orskov (1979) \\
\hline Ruminant calves $\mathrm{N}$-free infusates & 205 & 403 & $-\dagger$ & 406 & Present work \\
\hline Steers $\mathbf{N}$-free infusates & 342 & 295 & 25 & 325 & Present work \\
\hline $\begin{array}{l}\text { Cows } N \text {-free infusates } \\
\text { (mean of periods } a, b, c \text { ) }\end{array}$ & 600 & 296 & 25 & 320 & Present work \\
\hline Liquid-fed calves $\mathrm{N}$-free diet & 33 & 188 & 153 & 341 & Blaxter \& Wood (1951) \\
\hline Sheep N-free diets $\ddagger$ & 24 & 73 & 161 & 234 & Sotola $(1930)$ \\
\hline Sheep N-free diets $\ddagger$ & 27 & 102 & 138 & 240 & Turk et al. (1934) \\
\hline Sheep N-free diets & 34 & 62 & 128 & 190 & Harris \& Mitchell (1941) \\
\hline Sheep N-free diets & 34 & 73 & 128 & 201 & Ellis et al. (1956) \\
\hline
\end{tabular}

* $W^{0.75}$, metabolic live wt values giving total excretion and excretion per kg body-wt.

+ Small amount included in the urine.

$\ddagger \mathrm{N}$ intake less than $1 \mathrm{~g} / \mathrm{d}$.

Table 8 but they have been summarized by the Agricultural Research Council (1980) and on the whole give values similar to those obtained with $\mathrm{N}$-free diets and were used to obtain the Agricultural Research Council (1980) estimates for EUN included in Table 7.

Amounts of $\mathrm{N}$ excreted by calves given a liquid diet and $\mathrm{N}$-free diets expected to by-pass the rumen appear to be similar to our estimates (Blaxter \& Wood, 1951). The Agricultural Research Council (1980) estimate a total $\mathrm{N}$ excretion for pre-ruminant calves of $\mathrm{N}$-free diets derived by extrapolation of about $244 \mathrm{mg} / \mathrm{kg} \mathrm{W}^{\mathbf{7} 5}$. However, when functioning ruminants were given $\mathrm{N}$-free diets the $\mathrm{N}$ excretion differed in two important aspects from the animals given nutrients by infusion, the liquid-fed calves and the fasted animals. First, while the faecal $\mathrm{N}$ in the present work was negligible it can be seen that faecal $\mathrm{N}$ was approximately twice the amount of the urinary $N$, when $N$-free diets were given to normal functioning ruminants. Secondly, the total $\mathbf{N}$ excretion was lower with feeding of $\mathbf{N}$-free diets to functioning ruminants than with the other methods of supplying nutrients. There are good reasons for both. First, the urea recycled and trapped in microbial $\mathrm{N}$ will, at least in part, be excreted in the faeces. Confirmation of this is seen in the composition of urinary $\mathbf{N}$ from ruminants given $\mathrm{N}$-free diets (Table 6, Kehar et al. 1943), from which urea- $\mathrm{N}$ is virtually absent. It is most probable that it is the urea- $N$ which as a result of microbial fermentation is trapped and excreted via the faeces. The fact that food intake eventually ceases when $\mathrm{N}$-free diets are given to ruminants probably implies that the proportion which can be recycled, while substantial, is in the long-term insufficient to sustain rumen fermentation. The results of Clarke et al. (1962) and of many workers since have shown large increases in $\mathrm{N}$ in the gut between the mouth and duodenum. With sheep Clarke et al. (1962) found an addition of $N$ of $5-6 \mathrm{~g} / \mathrm{d}$.

A good reason why the total excretion may be lower with functioning ruminants sustained on $\mathrm{N}$-free diets, is that as long as fermentation occurs, microbial protein is being produced and digested and so the existence of protein-free diet is more apparent than real. As a result 
of recycling of $\mathrm{N}$ in this way it is reasonable to expect that the excretion essentially becomes limited to indigestible microbial residues and to urinary $\mathrm{N}$ which cannot be recycled. It also follows that EUN and MFN determined with $\mathrm{N}$-free diets do not give a complete measure of the minimal $\mathrm{N}$ metabolism.

The work on $\mathrm{N}$-free diets together with the effect of increasing the caecal fermentation (Ørskov et al. 1970) demonstrates that the endogenous $\mathrm{N}$ or that which would have been excreted in the form of urea could almost be entirely excreted in the faeces.

The $\mathrm{N}$ balance at fasting appears to be greater by only $20-30 \%$ than at energy maintenance in animals given an $\mathrm{N}$-free diet (Table 8). This would suggest that the $\mathrm{N}$ excreted is an inevitable loss and that whether the energy derives from absorption from the gut or from fat mobilization is of relatively little consequence as far as basal $\mathbf{N}$ metabolism is concerned at least for a period. It is of interest that Jakobsen (1958) mentioned experiments carried out in Copenhagen in which the endogenous urinary $\mathrm{N}$ excretion in cockerels was similar, regardless of whether the birds were starved or given $\mathrm{N}$-free diets, provided that the birds were in good condition when they were starved. Lean birds excreted more $\mathrm{N}$ at fasting than at energy maintenance.

\section{Creatinine excretion and minimal $N$ excretion}

The relative constancy of basal $\mathrm{N}$ and creatinine excretion (Tables 2-5) is in agreement with many reports in the literature and was reported many years ago by Palmer et al. (1914). Levels of $20-30 \mathrm{mg} / \mathrm{kg}$ live weight were usually reported (see Loffgren \& Garrett, 1954) and have been used to predict muscle mass. The fact that the steers excreted more per $\mathrm{kg}$ live weight than the cows may well reflect a greater proportion of muscle in the steers. Graystone (1968) showed that about $1 \mathrm{~g}$ creatinine was excreted daily per $20 \mathrm{~kg}$ of muscle mass. If this relationship is constant then it could be suggested that in ruminants the endogenous loss could be derived from determination of creatinine excretion rather than experiments of the nature reported here.

The relationship between total $\mathrm{N}$ excretion $(y)$ and creatinine excretion $(x)$ at zero protein uptake was $y=6.86 x+6.38$, and was highly significant $(r 0.86)$. Obviously caution must be applied where a source of creatinine is included in the diet, and more information is needed before such a procedure can be recommended. Terroine \& Sorg-Matter (1927) and Smuts (1935) showed, with simple-stomached animals, that urinary + faecal $N$ excretion on $\mathrm{N}$-free diets was related to basal metabolic rate. Mukherjee \& Mitchell (1949) showed that both basal metabolic rate and EUN increased after feeding with iodinized casein and that the value of creatinine:total $\mathrm{N}$ remained constant. It is thus possible that the minimal requirement of $\mathrm{N}$ could be predicted with sufficient accuracy from measurement of creatinine excretion in ruminants.

\section{Practical implications for feeding of ruminants}

In the new system of protein evaluation (Agricultural Research Council, 1980), the $\mathrm{N}$ required for tissue maintenance has been based on EUN and estimated to be in the region of 100 to $120 \mathrm{mg} / \mathrm{kg} \mathrm{W}^{0.73}$; MFN was taken as an inevitable consequence of microbial degradation of carbohydrate in food and was not implicated as a requirement, though a further measure of endogenous loss was accounted for by using apparent rather than true digestibility of protein in the small intestine. The underestimation of minimal protein requirement has the greatest effect on tissue requirement for low level feeding or undernutrition. If the supply of protein for an animal given energy sufficient only for maintenance consists of microbial protein alone, it is possible to compare the estimated microbial net contribution with that of the minimal need. If the requirement for metabolizable energy (ME) is taken to be $450 \mathrm{~kJ} / \mathrm{kg} \mathrm{W}^{0.75}$ (Ørskov, Grubb, Wenham et al. 1979) and the net supply 
of microbial amino acid N, 0.53 g/MJ ME (Agricultural Research Council, 1980), then the supply per $\mathrm{kg} \mathrm{W}^{0.75}$ would be $0.45 \times 0.53=240 \mathrm{mg}$, which is less than the minimal amount needed according to the estimates given in Tables 7 and 8 . If, however, the Agricultural Research Council estimates were based on true digestibility of protein in the small intestine of 0.85 and with consequent change in utilization to 0.80 (Storm \& Orskov, 1982), the contribution at energy maintenance would be $306 \mathrm{mg} \mathrm{N} / \mathrm{kg} \mathrm{W}^{0.75}$, i.e. close to the tissue maintenance requirement in the mature animal but insufficient for the young animal. If intakes of energy were less than requirements the deficit would be greater. On the other hand, if the need was based on EUN derived by extrapolation or from feeding of $\mathrm{N}$-free diets to functioning ruminants, there would be a considerable excess of protein when the animals were given their maintenance energy. Recent results (Hovell \& Ørskov, 1981) have provided some confirmation of the results obtained here. Lambs given a maintenance energy diet increased their growth rate when given a protein source which largely escaped rumen degradation. Similar results have been obtained by Smith et al. (1980) who demonstrated growth responses to additions of fish meal with heifers on a high-roughage diet, and Kemptom \& Leng (1979) with lambs.

Such underestimations of protein requirement with low level nutrition may help to explain compensatory growth in terms of the short-term responses to repletion of protein (Ørskov et al. 1976), and they might explain the surprising effect of undernutrition on the response in growth rate to protein escaping rumen degradation in older lambs, for which protein requirements were predicted to be satisfied by the microbial protein supply (Ørskov \& Grubb, 1979).

The authors wish to thank Dr R. N. B. Kay for helpful criticisms of this manuscript and Sir Kenneth Blaxter for helpful discussions.

\section{REFERENCES}

Agricultural Research Council (1980). Nutrient Requirements for Ruminants. Slough, England: Commonwealth Agricultural Bureau.

Blaxter, K. L. (1962). Br. J. Nutr. 16, 615.

Blaxter, K. L. (1964). In The Role of the Gastrointestinal Tract in Protein Metabolism, p. 143 [H. N. Munro, editor]. Oxford: Blackwell Scientific.

Blaxter, K. L. \& Mitchell, H. H. (1947). J. Anim. Sci. 6, 483.

Blaxter, K. L. \& Mitchell, H. H. (1948). J. Anim. Sci. 7, 351.

Blaxter, K. L. \& Wood, W. A. (1951). Br. J. Nutr. 5, 11.

Checal, U., Mehra, V. R., Nath, K. \& Ranjhan, S. K. (1975). J. agric. Sci., Camb. 84, 1.

Clarke, E. M. W., Ellinger, G. M. \& Phillipson, A. T. (1962). Proc. R. Soc. Ser. B 166, 63.

Davidson, J., Mathieson, J. \& Boyne, A. W. (1970). Analyst, Lond. 95, 181.

Elliot, R. C. \& Topps, J. H. (1967). Anim. Prod. 9, 219.

Ellis, W. C., Garner, G. B., Muhrer, M. E. \& Phander, W. H. (1956). J. Nutr. 60, 413.

Graystone, J. E. (1968). In Human Growth [D. B. Cheek, editor]. Philadelphia: Lea \& Febiger.

Harris, L. E. \& Mitchell, H. H. (1941). J. Nutr. 22, 167.

Hawk, P. B., Oser, B. L. \& Summerson, W. H. (1947). In Practical Physiological Chemistry, p. 506. San Francisco: McGraw Hill Co.

Hovell, F. D. \& Ørskov, E. R. (1981). Anim. Prod. (In the Press).

Jakobsen, P. E. (1958). In Dyrefysiologi, Den Kgi Vet og Landbohojskole Copenhagen, p. 267.

Kehar, N. D., Mukherjee, R. \& Senk, C. (1943). Indian J. vet. Sci. 13, 257.

Kempton, T. J. \& Leng, R. A. (1979). Br. J. Nutr. 39, 105.

Loffgren, G. P. \& Garrett, W. N. (1954). J. Anim. Sci. 13, 496.

Marsh, W. H., Fingerhut, B. \& Miller, H. (1965). Clin. Chem. 11, 624.

Mason, V. C. (1969). J. agric. Sci., Camb. 73, 99.

Mitchell, H. H. (1926). Bull. US natn. Res. Counc. No. 55.

Morris, S. \& Roy, S. C. (1939). Biochem. J. 33, 1217.

Mukherjee, R, \& Mitchell, H. H. (1949). J. Nutr. 37, 303.

Ørskov, E. R., Fraser, C., Mason, V. C. \& Mann, S. O. (1970). Br. J. Nutr. 24, 671.

Ørskov, E. R. \& Grubb, D. A. (1978). Proc. Nutr. Soc. 38, 24 A.

Orskov, E. R. \& Grubb, D. A. (1979). Anim. Prod. 29, 371. 
Ørskov, E. R., Grubb, D. A., Smith, J. S., Webster, A. J. F. \& Corrigal, W. (1979). Br. J. Nutr. $41,541$.

Ørskov, E. R., Grubb, D. A., Wenham, G. \& Corrigal, W. (1979). J. Nutr. 41, 553.

Orskov, E. R., McDonald, I., Grubb, D. A. \& Pennie, I. (1976). J. agric. Sci., Camb. 86, 411.

Palmer, W. W., Means, J. H. \& Gamble, J. L. (1914). J. biol. Chem. 19, 239.

Smith, T., Broster, V. J. \& Hill, R. E. (1980). J. agric. Sci., Camb. (In the Press).

Smuts, D. B. (1935). J. Nutr. 9, 403.

Sotola, J. (1930). J. agric. Res., Camb. 40, 79.

Storm, E. \& Orskov, E. R. (1979). Ann. Rech. Vet. 10, 297.

Storm, E. \& Orskov, E. R. (1982). Proc. Nutr. Soc. (In the Press).

Terroine, E. F. \& Sorg-Matter, H. (1927). Archs int. Physiol. 29, 121.

Topps, J. T. \& Elliot, R. C. (1967). Anim. Prod. 9, 219.

Turk, K. L., Momsen, F. B. \& Maynard, L. A. (1934). J. agric. Res., Camb. 48, 555.

Verite, R., Journet, M. \& Jarrige, R. (1979). Livestock Prod. Sci. 6, 349.

Walker, D. M. \& Faichney, G. J. (1964a). Br. J. Nutr. 18, 187.

Walker, D. M. \& Faichney, G. J. (1964b). Br. J. Nutr. 18, 201. 